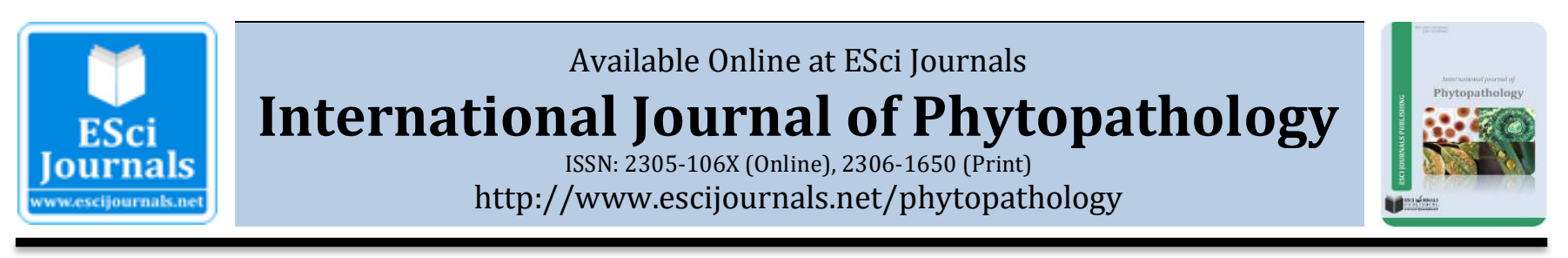

\title{
PATHOGENIC VARIATION OF COLLETOTRICHUM LINDEMUTHIANUM CAUSING ANTHRACNOSE OF BEANS (PHASEOLUS VULGARIS) IN UGANDA
}

\author{
aMoses J. Kiryowa, aAston Ebinu, bVincent Kyaligonza, bStanley T. Nkalubo, \\ bPamela Paparu, cClare Mukankusi, aPhinehas Tukamuhabwa \\ a Dept. of Agricultural Production, College of Agricultural \& Environmental Sciences, Makerere University, Uganda. \\ ${ }^{b}$ National Crops Resources Research Institute (NaCRRI), NARO, Kampala, Uganda. \\ c Centro Internacional de Agricultura Tropical (CIAT), Kampala, Uganda.
}

\begin{abstract}
A B S T R A C T
Colletotrichum lindemuthianum is a highly variable pathogen of common beans that easily overcomes resistance in cultivars bred with single-gene resistance. To determine pathogenic variability of the pathogen in Uganda, samples of common bean tissues with anthracnose symptoms were collected in eight districts of Uganda, namely Kabarole, Sironko, Mbale, Oyam, Lira, Kapchorwa, Maracha and Kisoro. 51 isolates sporulated successfully on Potato Dextrose Agar and Mathur's media and were used to inoculate 12 differential cultivars under controlled conditions. Five plants per cultivar were inoculated with each isolate and then evaluated for their reaction using the $1-9$ severity scale. Races were classified using the binary nomenclature system proposed by Pastor Corrales (1991). Variation due to cultivar and isolate effects was significant $(\mathrm{P} \leq 0.001)$ for severity. The 51 isolates from eight districts grouped into 27 different races. Sironko district had the highest number of races followed by Mbale and Kabarole. Races 2047 and 4095 were the most frequently found, each with 10 isolates grouped under them. Race 4095 was the most virulent since it caused a susceptible (S) reaction on all 12 differential cultivars and the susceptible check. This was followed by races 2479, 2047 and 2045 respectively. Two races, 4094 and 2479, caused a susceptible reaction on the differential cultivar G2333, which nevertheless, showed the most broad spectrum resistance followed by cultivars Cornell 49-242, TU, and AB136 respectively. These cultivars are recommended for use in breeding programs aiming at breeding for broad spectrum resistance to bean anthracnose in Uganda.
\end{abstract}

Keywords: Broad spectrum, races, virulence, diversity, pathotypes.

\section{INTRODUCTION}

The pathogen Colletotrichum lindemuthianum (Sacc. and Magn.) Lams.-Scrib has a wide pathogenic variation with various races reported in major bean producing countries such as Mexico and Brazil (Balardin and Kelly, 1998). The highest diversity and variation are reported in Latin America, which is the center of origin of common beans (Pastor-Corrales et al., 1995). The East African highland region is regarded as the secondary center of diversity of common beans (Schwartz and Pastor-Corrales, 1989) and due to co-evolution is expected to have a high diversity of $C$. lindemuthianum. Mahuku and Riascos (2004) assessed virulence and

\footnotetext{
* Corresponding Author:

Email: m.kiryowa@gmail.com

(C) 2016 ESci Journals Publishing. All rights reserved.
}

\begin{abstract}
molecular diversity of 200 Colletotrichum lindemuthianum isolates collected from Andean and Mesoamerican bean cultivars and regions. They reported high levels of pathotypic ( 90 pathotypes) diversity among the 200 isolates. Bigirimana et al. (2000) identified nine $C$. lindemuthianum races using 12 isolates collected from major bean growing areas in Burundi and 12 standard differential cultivars. Races 9, 69, 87, 384, $385,401,448,449$ and 485 were identified. Seven of these races were reported for the first time in Burundi. In Uganda, Leaky and Simbwa-Bunnya (1972) using differential cultivars from Shreiber and Hubberling, identified races 17, 19, 23, 102, 130, and 453 with isolates collected from Central, Western and South Western regions of Uganda. More recently, races 23, $55,102,130,227,375,511$ and 767 were reported from
\end{abstract}


Kabale, Kisoro, Bushenyi and Mpigi districts with race 767 reported as the most widespread and virulent (Nkalubo, 2006). Three races of these namely 23, 102 and 130 were similar to those reported by Leaky and Simbwa-Bunnya (1972). Mwesigwa (2008) reported 21 races $(0,2,3,4,6,14,128,262,264,268,320,452,481$, 1024, 1536, 1538, 1856, 1857, 1989, 3086 and 4033) out of 47 isolates collected from Kabale, Apac, Mbale, Mpigi and Wakiso districts. None of these races were similar to the ones in the earlier studies and two highly virulent races 3086 and 4033 caused symptoms on the highly resistant differential cultivar G2333. Nine of the races were virulent to the Mesoamerican cultivars, three races were virulent to the Andean cultivars and seven races were virulent to both groups of cultivars.

There is a wide gap in time from the work of Leakey and Simbwa-Bunnya (1972) to that of Nkalubo (2006) and Mwesigwa (2008) to suspect change in diversity of the pathogen because of increase in bean production, introduction of new varieties from different gene pools and movement of bean seed within the country and region. The differences in physiological races from the earlier studies could be because of emergence or introduction of new races that overcome previously stable resistances among the bean differential set. The aim of this study was to determine the current pathogenic variation of $C$. lindemuthianum in bean growing districts in Uganda.

\section{MATERIALS AND METHODS}

Collection of $\boldsymbol{C}$. lindemuthianum samples: Farmers' fields were selected purposively depending on presence of bean anthracnose disease. Bean pods with symptoms of anthracnose disease were collected from different cultivars from eight districts of Uganda namely Kabarole, Kapchorwa, Kisoro, Lira, Maracha, Mbale, Oyam and Sironko representing the Western, South Western, Eastern, Northern and North Western regions. A $1 \mathrm{M}^{2}$ sampling quadrant was used in the farmers' fields to select plants from a given part of the field, which were used for data and sample collection. Data was collected on disease incidence and severity. Diseased bean pod samples were collected from the sampled fields, placed in polythene bags and stored in boxes. A GPS machine was used to determine altitude and coordinates of fields where samples were picked.

Isolation $C$. lindemuthianum and inoculum preparation: Isolation of the fungus was done according to the method described by Balardin et al. (1997). Infected tissues from the bean pods were cut into small pieces of up to $5 \mathrm{~cm}$ long. The tissues were placed into a small beaker and $10 \mathrm{ml}$ of Sodium hypochlorite (Jik) bleach was added and after two minutes, the bleach was removed and $10 \mathrm{ml}$ of ethanol was added and two minutes later the ethanol was removed and the tissues rinsed with sterilized water. The tissues were placed on filter paper to remove excess water and dry them. The tissues were placed on PDA media and incubated in darkness at $22-24^{\circ} \mathrm{C}$ and after four days, the different cultures were subcultured onto modified Mathur's Agar media (500g) made up of $4 \mathrm{~g}$ of Dextrose, 1.25g of Magnesium Sulfate, $1.35 \mathrm{~g}$ of Potassium Phosphate, $1.2 \mathrm{~g}$ of Neopeptone, $1 \mathrm{~g}$ of Yeast extract and 8g of Agar, to get pure isolates and increase sporulation (Champion et al., 1973).

Single-spore isolates were placed on fresh Mathur's agar medium in a Petri dish and incubated at $22-24{ }^{\circ} \mathrm{C}$ for 7 to 10 days to allow the fungus enough time to produce conidial spores (Balardin et al., 1997). For inoculation purposes, conidial spores were scrapped off the growth medium into a small amount of water to make a suspension. Using a hemocytometer the concentration was adjusted to $1.2 \times 10^{6}$ conidia $\mathrm{ml}^{-1}$ (Inglis et al., 1988) and $0.1 \%$ Tween 20 was added as a surfactant. 


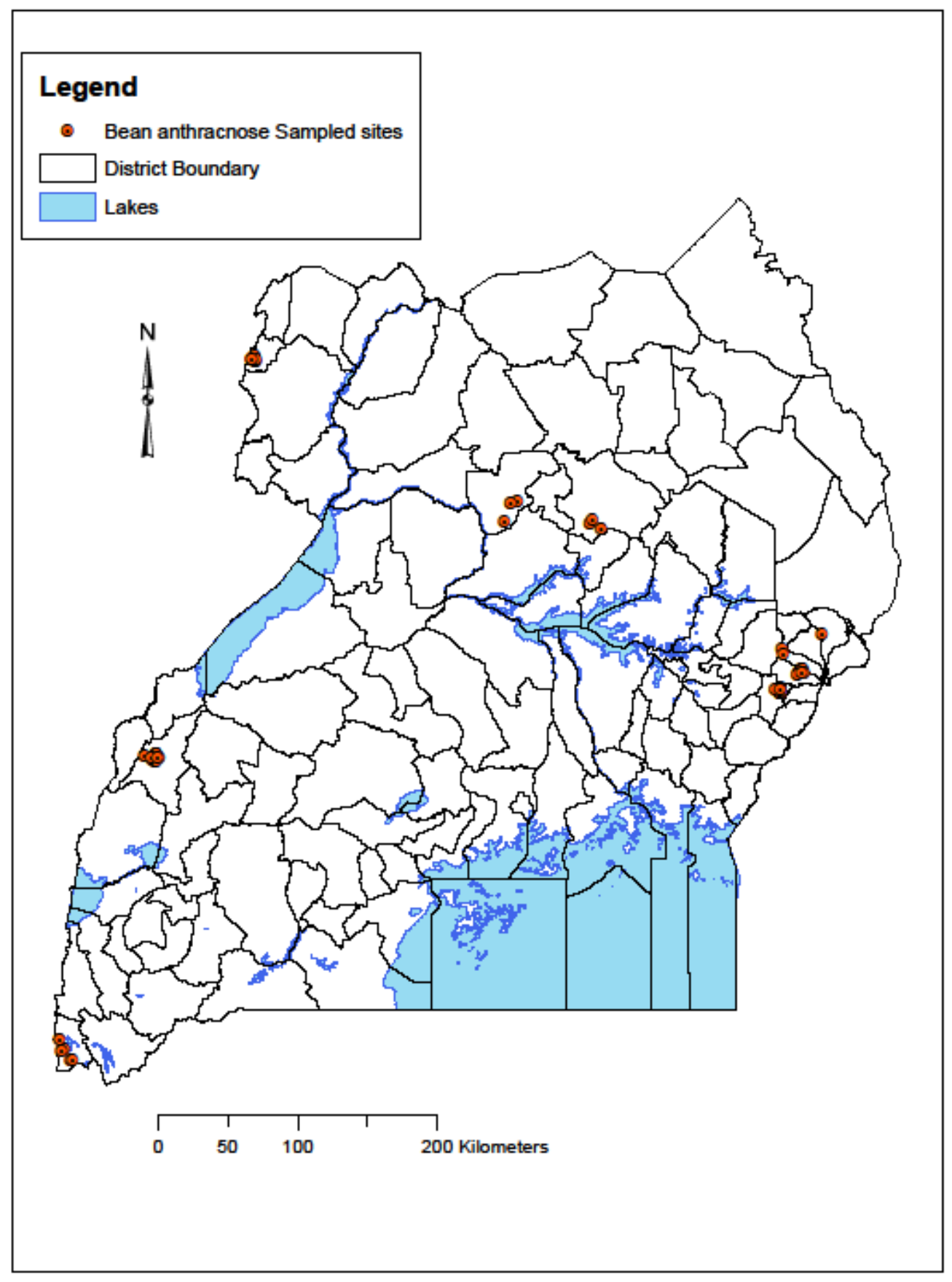

Figure 1. Map of Uganda indicating sampling areas for bean anthracnose.

Inoculation: Seed of the 12 differential cultivars (Table 1) were pre-germinated and later soaked for 30 minutes into the inoculum before transplanting into sterilized soil mixed with saw dust, in a controlled screen house at the National Crops Resources Research Institute (NaCRRI). Five seeds of each of the 12 differential cultivars were sowed in a tray plus a known susceptible check K132. The screen house conditions were maintained at $95-100 \%$ relative humidity and temperature of $22 \pm 2^{\circ} \mathrm{C}$. Disease severity was scored $10-$ 14 days after planting using a modified 1 - 9 scale (Balardin et al., 1997) Where; $1=$ no symptoms (resistant), $2-3$ = very small lesions mostly on primary leaves (resistant) and 4-9 = numerous enlarged lesions or sunken cankers on the lower side of the leaves or hypocotyls (susceptible). 
Int. J. Phytopathol. 05 (03) 2016. 89-98
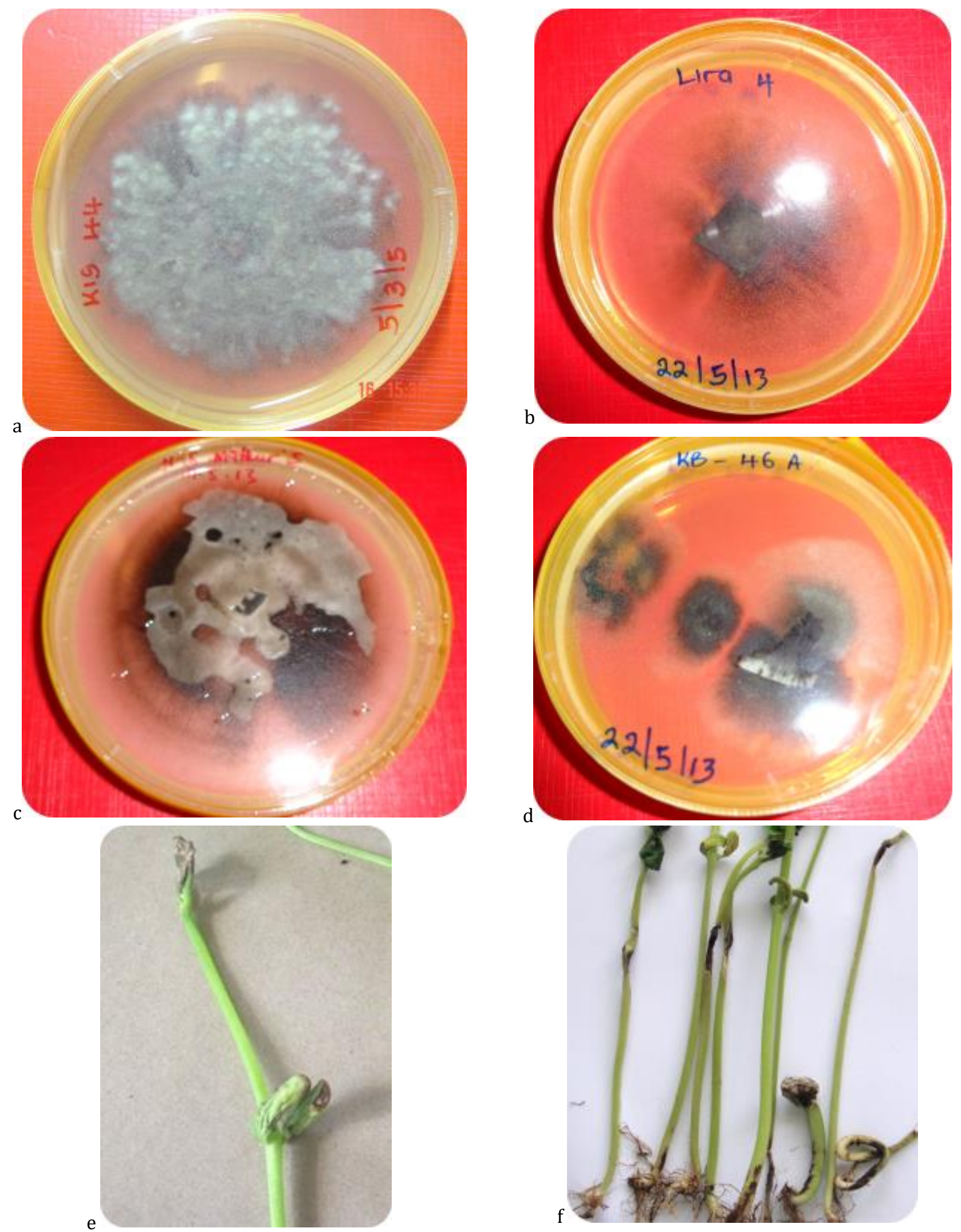

a
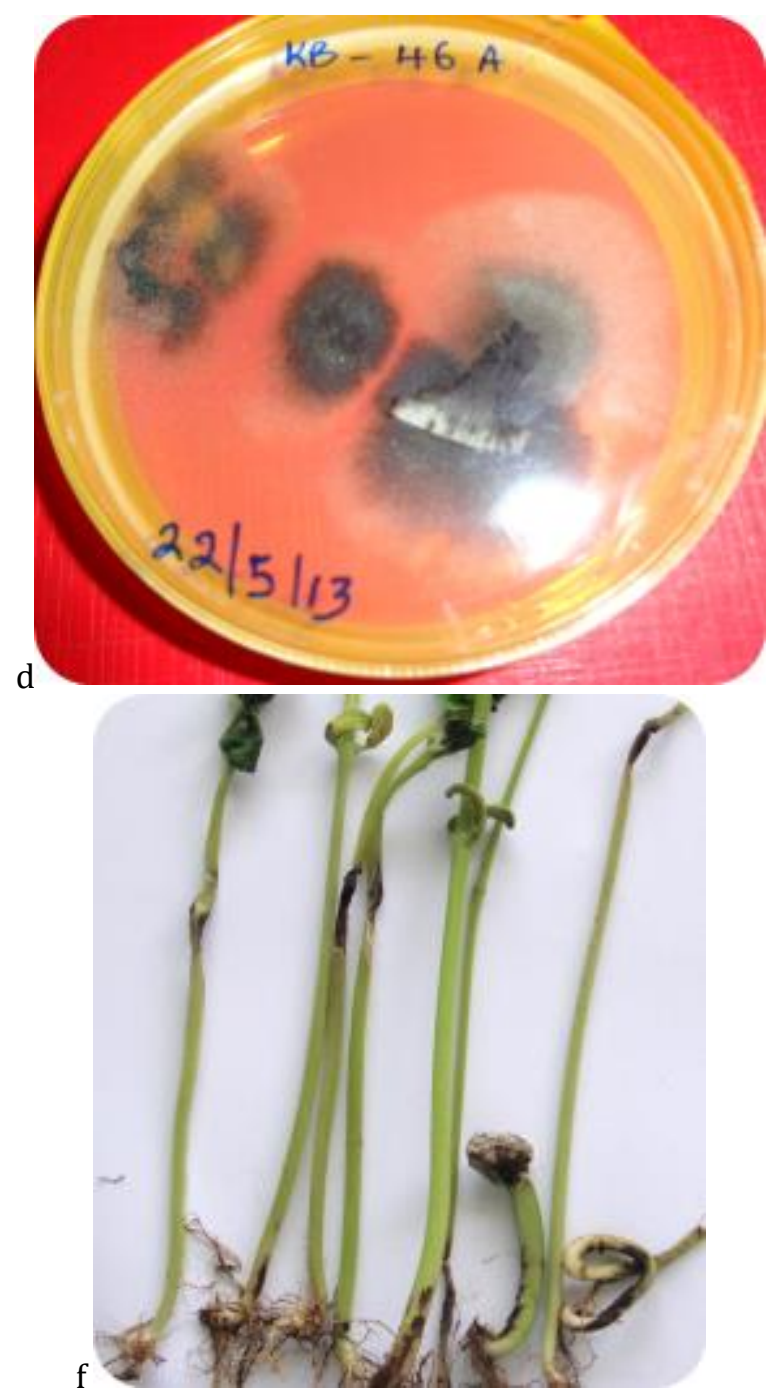

Plate: 1: a to d; Cultures of C. lindemuthianum isolates - Kis 44, Lira 4, N5 and KB46A; e \& f; Anthracnose symptoms on inoculated pre-germinated seedlings of differentia cultivars. 


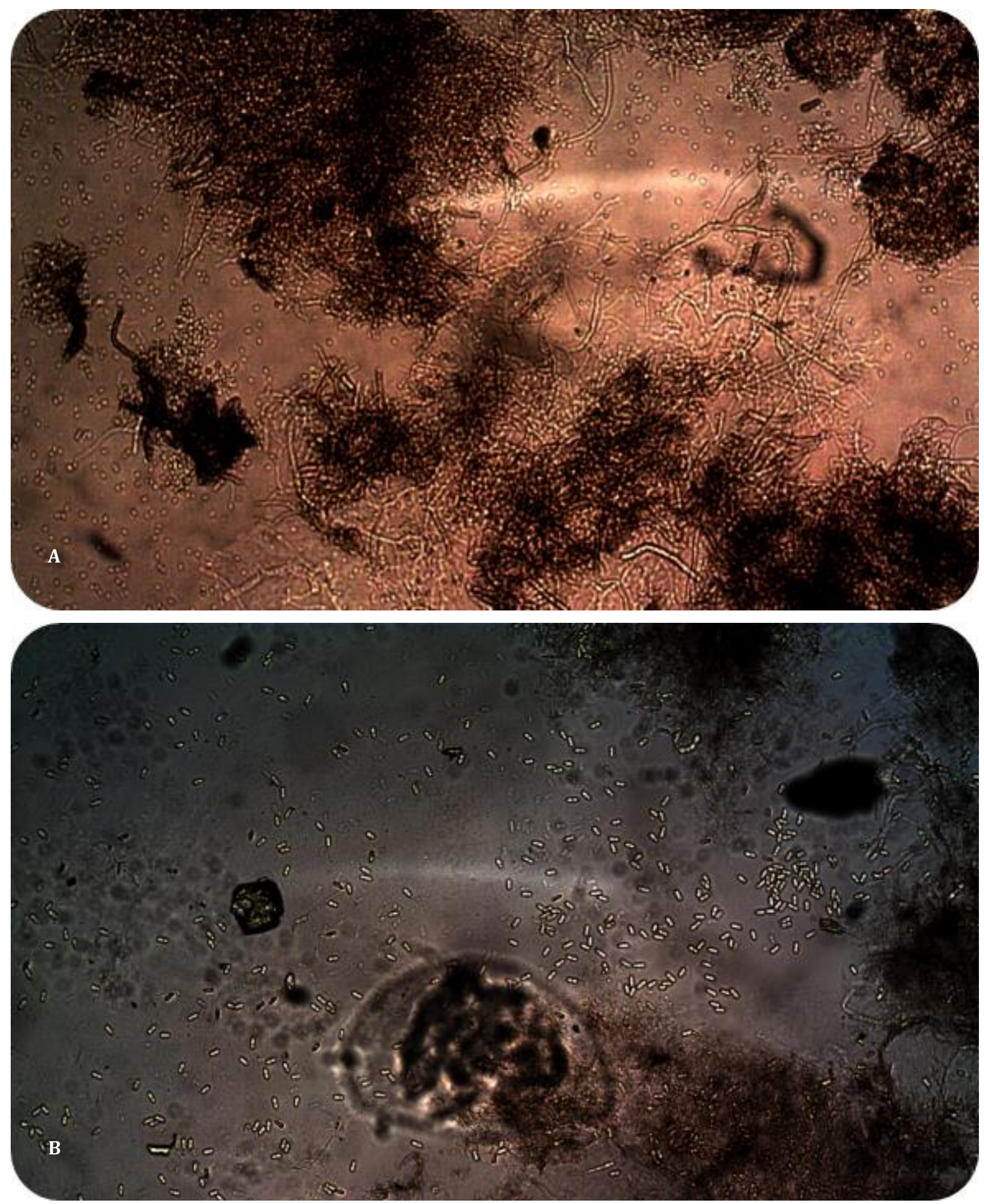

Plate 2: A; Conidia of Isolate N2.

B; Conidia of Isolate KIS33A. 
Int. J. Phytopathol. 05 (03) 2016. 89-98

Table 1. Standard differential cultivars used to characterize $C$. lindemuthianum, their binary codes, resistance genes and gene pool.

\begin{tabular}{|c|c|c|c|c|c|}
\hline Differential Cultivar & Seed Type ${ }^{a}$ & Notation & Binary Code & Resistance Gene & Gene Pool b \\
\hline Michelite & $\mathrm{S}$ & 0 & 1 & Co-11 & MA \\
\hline Michigan Dark Red Kidney & $\mathrm{L}$ & 1 & 2 & $\mathrm{Co}-1$ & A \\
\hline Perry Marrow & $\mathrm{L}$ & 2 & 4 & Co-13 & A \\
\hline Cornell 49-242 & $S$ & 3 & 8 & Co-2 & MA \\
\hline Widusa & $\mathrm{L}$ & 4 & 16 & Co-15 & A \\
\hline Kaboon & $\mathrm{L}$ & 5 & 32 & Co-12 & A \\
\hline Mexico 222 & $\mathrm{~S}$ & 6 & 64 & Co-3 & MA \\
\hline PI 207262 & $S$ & 7 & 128 & Сo-43 Co-9 & MA \\
\hline TO & $S$ & 8 & 256 & Co-4 & MA \\
\hline TU & $\mathrm{S}$ & 9 & 512 & $\mathrm{Co}-5$ & MA \\
\hline AB 136 & $S$ & 10 & 1024 & Co-6 & MA \\
\hline G2333 & $\mathrm{S}$ & 11 & 2048 & Co-42 Co-52 Co-7 & MA \\
\hline
\end{tabular}

a S = Small seeded; L = Large seeded. b MA= Middle American; A= Andean ; Source: Awale et al., (2007).

Race determination: To identify races, the binary system was used based on the sum of binary values assigned to each of the 12 differential cultivars proposed by PastorCorrales (1991) to characterize anthracnose races. Each differential cultivar had an assigned number $2^{n}$ where $n$ corresponds to the place occupied by the cultivar within the differential series. The designation of a race number was obtained by summing the numerical values of all differential cultivars exhibiting susceptible (S) reactions to the isolate used for inoculation. Isolates with similar reactions on the differentials were grouped to form a race. RESULTS AND DISCUSSION

Race determination: The reaction of 51 isolates on the 12 standard differentials is presented in Table 2. The isolates were grouped into 27 races of different patterns of virulence. Races 2047 and 4095 were the most abundant. Race 4095 was the most virulent causing a susceptible reaction on all the 12 differential cultivars and the susceptible check. This was followed by races 2047, 20452039 and 2023. Race 2047 comprised of 10 isolates collected from five districts namely Kabarole, Kisoro, Maracha, Mbale and Sironko.

Race distribution: Race 2479 comprised of one isolate collected from Sironko district, while race 4095 comprised of 10 isolates collected from seven districts of Kabarole, Kapchorwa, Kisoro, Oyam, Mbale, Maracha and Sironko. This makes race 4095 the most widely distributed followed by race 4027. Sironko and Mbale districts in the Eastern region of Uganda had the highest number of races including the most virulent ones followed by Kabarole district in the West and Kisoro district in the South western region. These are all high altitude bean growing regions ranging from 1429 $1860 \mathrm{~m}$ above sea level and therefore offer favorable conditions for the development and spread of bean anthracnose disease.

Table 3 shows incidences and severity of bean anthracnose in the sampled districts. Sironko district had the highest incidence (76\%) and severity (4.3), followed by Mbale $(75 \%, 4.0)$, Maracha $(45 \%, 2.6)$ in West Nile and Oyam $(31 \%, 1.5)$ in the North. Most of the varieties sampled were local or variety mixtures, as it is the habit of farmers to mix different varieties. K132 was the only improved variety observed in Maracha out of all the districts sampled. It is worth noting that bean anthracnose disease was not observed in Zombo district of West Nile despite the fact that it is a highland locale with favorable conditions for the disease to flourish.

This study revealed a high level of pathogenic variability of $C$. lindemuthianum with 27 races identified from 51 isolates collected from major bean growing districts in Uganda. Mwesigwa (2008) similarly revealed a high level of variability of $C$. lindemuthianum in Uganda with 21 races identified from 47 isolates. With the use RAPD and rep-markers, Mwesigwa (2008) grouped the isolates in to three subgroups, which differed greatly from his results obtained using the differential cultivars.

Only three races in this study were similar to races reported earlier in Uganda namely race 0 and 128 (Mwesigwa, 2008) and race 767 (Nkalubo, 2006). The race 767 was reported by Nkalubo (2006) as the most abundant and aggressive while the races 1024, 1536, 1538, 1856, 1857, 1989, 3086 and 4033 were reported by Mwesigwa (2008) as the most aggressive. 
Table 2. Response of 12 differential cultivars to $C$. lindemuthianum isolates

\begin{tabular}{|c|c|c|c|c|c|c|c|c|c|c|c|c|c|}
\hline \multirow{3}{*}{ Race* } & \multicolumn{13}{|c|}{ Differential cultivars and their respective resistance genes a } \\
\hline & 1 & 2 & 3 & 4 & 5 & 6 & 7 & 8 & 9 & 10 & 11 & 12 & \\
\hline & Co-11 & Co-1 & Co- $1^{3}$ & Co-2 & Co- $1^{5}$ & $\mathrm{Co}-1^{2}$ & Co-3 & $\begin{array}{c}\text { Co- } 4^{3}, \\
\text { Co-9 }\end{array}$ & Co-4 & Co-5 & $\begin{array}{l}\text { Co-6, } \\
\text { co-8 }\end{array}$ & $\begin{array}{c}\mathrm{Co}-4^{2}, \mathrm{Co}^{2} 5^{2} \\
\mathrm{Co}-7\end{array}$ & Isolates \\
\hline 0 & $\mathrm{R}$ & $\mathrm{R}$ & $\mathrm{R}$ & $\mathrm{R}$ & $\mathrm{R}$ & $\mathrm{R}$ & $\mathrm{R}$ & $\mathrm{R}$ & $\mathrm{R}$ & $\mathrm{R}$ & $\mathrm{R}$ & $\mathrm{R}$ & $38 \mathrm{~A}, 59 \mathrm{~A}, 57 \mathrm{~A}, 25 \mathrm{~A}$ \\
\hline 1 & $\mathrm{~S}$ & $\mathrm{R}$ & $\mathrm{R}$ & $\mathrm{R}$ & $\mathrm{R}$ & $\mathrm{R}$ & $\mathrm{R}$ & $\mathrm{R}$ & $\mathrm{R}$ & $\mathrm{R}$ & $\mathrm{R}$ & $\mathrm{R}$ & $82 \mathrm{~A}$ \\
\hline 42 & $\mathrm{R}$ & $\mathrm{S}$ & $\mathrm{R}$ & $\mathrm{S}$ & $\mathrm{R}$ & $\mathrm{S}$ & $\mathrm{R}$ & $\mathrm{R}$ & $\mathrm{R}$ & $\mathrm{R}$ & $\mathrm{R}$ & $\mathrm{R}$ & $85 \mathrm{~A}$ \\
\hline 81 & $\mathrm{~S}$ & $\mathrm{R}$ & $\mathrm{R}$ & $\mathrm{R}$ & $\mathrm{S}$ & $\mathrm{R}$ & $\mathrm{S}$ & $\mathrm{R}$ & $\mathrm{R}$ & $\mathrm{R}$ & $\mathrm{R}$ & $\mathrm{R}$ & $92 \mathrm{~A}$ \\
\hline 128 & $\mathrm{R}$ & $\mathrm{R}$ & $\mathrm{R}$ & $\mathrm{R}$ & $\mathrm{R}$ & $\mathrm{R}$ & $\mathrm{R}$ & $\mathrm{S}$ & $\mathrm{R}$ & $\mathrm{R}$ & $\mathrm{R}$ & $\mathrm{R}$ & $36 \mathrm{~A}$ \\
\hline 352 & $\mathrm{R}$ & $\mathrm{R}$ & $\mathrm{R}$ & $\mathrm{R}$ & $\mathrm{R}$ & $\mathrm{S}$ & $\mathrm{S}$ & $\mathrm{R}$ & $\mathrm{S}$ & $\mathrm{R}$ & $\mathrm{R}$ & $\mathrm{R}$ & $84 \mathrm{~A}$ \\
\hline 386 & $\mathrm{R}$ & $\mathrm{S}$ & $\mathrm{R}$ & $\mathrm{R}$ & $\mathrm{R}$ & $\mathrm{R}$ & $\mathrm{R}$ & $\mathrm{S}$ & $\mathrm{S}$ & $\mathrm{R}$ & $\mathrm{R}$ & $\mathrm{R}$ & $61 \mathrm{~A}$ \\
\hline 503 & $S$ & $\mathrm{~S}$ & $\mathrm{~S}$ & $\mathrm{R}$ & $\mathrm{S}$ & $S$ & $\mathrm{~S}$ & $\mathrm{~S}$ & $\mathrm{~S}$ & $\mathrm{R}$ & $\mathrm{R}$ & $\mathrm{R}$ & $88 \mathrm{~A}$ \\
\hline 704 & $\mathrm{R}$ & $\mathrm{R}$ & $\mathrm{R}$ & $\mathrm{R}$ & $\mathrm{R}$ & $\mathrm{R}$ & $\mathrm{S}$ & $\mathrm{S}$ & $\mathrm{R}$ & $\mathrm{S}$ & $\mathrm{R}$ & $\mathrm{R}$ & $34 \mathrm{~A}$ \\
\hline 713 & S & $\mathrm{R}$ & $\mathrm{R}$ & $S$ & $\mathrm{R}$ & $\mathrm{R}$ & $\mathrm{S}$ & $S$ & $\mathrm{R}$ & S & $\mathrm{R}$ & $\mathrm{R}$ & $86 \mathrm{~A}$ \\
\hline 767 & $\mathrm{~S}$ & $\mathrm{~S}$ & $\mathrm{~S}$ & $\mathrm{~S}$ & $\mathrm{~S}$ & $\mathrm{~S}$ & $\mathrm{~S}$ & $\mathrm{~S}$ & $\mathrm{R}$ & $\mathrm{S}$ & $\mathrm{R}$ & $\mathrm{R}$ & $69 \mathrm{~A}$ \\
\hline 784 & $\mathrm{R}$ & $\mathrm{R}$ & $\mathrm{R}$ & $\mathrm{R}$ & $S$ & $\mathrm{R}$ & $\mathrm{R}$ & $\mathrm{R}$ & $\mathrm{S}$ & $S$ & $\mathrm{R}$ & $\mathrm{R}$ & $56 \mathrm{~A}$ \\
\hline 1023 & $\mathrm{~S}$ & $\mathrm{~S}$ & $S$ & $S$ & $\mathrm{~S}$ & $S$ & $S$ & $S$ & $\mathrm{~S}$ & $S$ & $\mathrm{R}$ & $\mathrm{R}$ & $62 \mathrm{~A}$ \\
\hline 1094 & $\mathrm{R}$ & $\mathrm{S}$ & $\mathrm{S}$ & $\mathrm{R}$ & $\mathrm{R}$ & $\mathrm{R}$ & $\mathrm{S}$ & $\mathrm{R}$ & $\mathrm{R}$ & $\mathrm{R}$ & $\mathrm{S}$ & $\mathrm{R}$ & $12 \mathrm{~A}$ \\
\hline 1169 & $\mathrm{~S}$ & $\mathrm{R}$ & $\mathrm{R}$ & $\mathrm{R}$ & $\mathrm{S}$ & $\mathrm{R}$ & $\mathrm{R}$ & $\mathrm{S}$ & $\mathrm{R}$ & $\mathrm{R}$ & $\mathrm{S}$ & $\mathrm{R}$ & $72 \mathrm{~A}$ \\
\hline 1175 & $S$ & $S$ & $S$ & $\mathrm{R}$ & $S$ & $\mathrm{R}$ & $\mathrm{R}$ & $\mathrm{S}$ & $\mathrm{R}$ & $\mathrm{R}$ & $S$ & $\mathrm{R}$ & $91 \mathrm{~A}$ \\
\hline 1334 & $\mathrm{R}$ & $\mathrm{S}$ & $\mathrm{S}$ & $\mathrm{R}$ & $\mathrm{S}$ & $\mathrm{S}$ & $\mathrm{R}$ & $\mathrm{R}$ & $\mathrm{S}$ & $\mathrm{R}$ & $S$ & $\mathrm{R}$ & $94 \mathrm{~A}$ \\
\hline 1471 & $\mathrm{~S}$ & $\mathrm{~S}$ & $\mathrm{~S}$ & $\mathrm{~S}$ & $\mathrm{~S}$ & $\mathrm{~S}$ & $\mathrm{R}$ & $\mathrm{S}$ & $\mathrm{S}$ & $\mathrm{R}$ & $\mathrm{S}$ & $\mathrm{R}$ & $90 \mathrm{~A}, 100 \mathrm{~A}$ \\
\hline 1527 & $\mathrm{~S}$ & $\mathrm{~S}$ & $\mathrm{~S}$ & $\mathrm{R}$ & $\mathrm{S}$ & $\mathrm{S}$ & $\mathrm{S}$ & $\mathrm{S}$ & $\mathrm{S}$ & $\mathrm{R}$ & $\mathrm{S}$ & $\mathrm{R}$ & $16 \mathrm{~A}, 99 \mathrm{~A}$ \\
\hline 1791 & $\mathrm{~S}$ & $\mathrm{~S}$ & $\mathrm{~S}$ & $\mathrm{~S}$ & $\mathrm{~S}$ & $\mathrm{~S}$ & $\mathrm{~S}$ & $\mathrm{~S}$ & $\mathrm{R}$ & $\mathrm{S}$ & $\mathrm{S}$ & $\mathrm{R}$ & $41 \mathrm{~A}$ \\
\hline 1834 & $\mathrm{R}$ & $\mathrm{S}$ & $\mathrm{R}$ & $\mathrm{S}$ & $\mathrm{R}$ & $\mathrm{S}$ & $\mathrm{R}$ & $\mathrm{R}$ & $\mathrm{S}$ & $\mathrm{S}$ & $\mathrm{S}$ & $\mathrm{R}$ & $81 \mathrm{~A}$ \\
\hline 2023 & $\mathrm{~S}$ & $\mathrm{~S}$ & $\mathrm{~S}$ & $\mathrm{R}$ & $\mathrm{R}$ & $\mathrm{S}$ & $\mathrm{S}$ & $\mathrm{S}$ & $\mathrm{S}$ & $\mathrm{S}$ & $\mathrm{S}$ & $\mathrm{R}$ & 007A \\
\hline 2039 & $\mathrm{~S}$ & $\mathrm{~S}$ & $\mathrm{~S}$ & $\mathrm{R}$ & $\mathrm{S}$ & $\mathrm{S}$ & $\mathrm{S}$ & $\mathrm{S}$ & $\mathrm{S}$ & $\mathrm{S}$ & $\mathrm{S}$ & $\mathrm{R}$ & $97 \mathrm{~A}$ \\
\hline 2045 & $\mathrm{~S}$ & $\mathrm{R}$ & $\mathrm{S}$ & $\mathrm{S}$ & $\mathrm{S}$ & $\mathrm{S}$ & $\mathrm{S}$ & $\mathrm{S}$ & $\mathrm{S}$ & $\mathrm{S}$ & $\mathrm{S}$ & $\mathrm{R}$ & $95 \mathrm{~A}, 40 \mathrm{~A}$ \\
\hline 2047 & $\mathrm{~S}$ & $\mathrm{~S}$ & $\mathrm{~S}$ & $\mathrm{~S}$ & $\mathrm{~S}$ & $\mathrm{~S}$ & $\mathrm{~S}$ & $\mathrm{~S}$ & $\mathrm{~S}$ & $\mathrm{~S}$ & $\mathrm{~S}$ & $\mathrm{R}$ & $\begin{array}{r}65 \mathrm{~A}, 08 \mathrm{~A}, 64 \mathrm{~A}, 75 \mathrm{~A}, 98 \mathrm{~A}, \\
52 \mathrm{~A}, 55 \mathrm{~A}, 37 \mathrm{~A}, 46 \mathrm{~A}, 71 \mathrm{~A}\end{array}$ \\
\hline 2479 & $\mathrm{~S}$ & $\mathrm{~S}$ & $\mathrm{~S}$ & $\mathrm{~S}$ & $\mathrm{R}$ & $\mathrm{S}$ & $\mathrm{R}$ & $\mathrm{S}$ & $\mathrm{S}$ & $\mathrm{R}$ & $\mathrm{R}$ & $\mathrm{S}$ & $83 \mathrm{~A}$ \\
\hline 4095 & $\mathrm{~S}$ & $\mathrm{~S}$ & $\mathrm{~S}$ & $\mathrm{~S}$ & $\mathrm{~S}$ & $\mathrm{~S}$ & $S$ & $S$ & $S$ & $S$ & $S$ & $S$ & $\begin{array}{l}66 \mathrm{~A}, 63 \mathrm{~A}, 44 \mathrm{~A}, 67 \mathrm{~A}, 76 \mathrm{~A} \\
28 \mathrm{~A}, 001 \mathrm{~A}, 77 \mathrm{~A}, 73 \mathrm{~A}, 96 \mathrm{~A}\end{array}$ \\
\hline
\end{tabular}

*Races characterized using the binary system (Pastor Coralles, 1991); Resistant reaction (R); Susceptible reaction (S)

a Differential cultivars: 1 = Michelite; 2 = MDRK; 3 = Perry Marrow; 4 = Cornell 49-242; 5 = Widusa; 6 = Kaboon; 7 = Mexico 222; 8 = PI $207262 ; 9=$ TO; 10 = TU; $11=\mathrm{AB} 136 ;$ and $12=\mathrm{G} 2333$ 
Table 3. Incidence, Severity and races of $C$. lindemuthianum by district.

\begin{tabular}{cccll}
\hline District & $\begin{array}{c}\text { Incidence } \\
(\%)\end{array}$ & $\begin{array}{c}\text { Severity } \\
(1-5)\end{array}$ & \multicolumn{1}{c}{ Cultivars sampled } & \multicolumn{1}{c}{ Races } \\
\hline Lira & 23 & 2.3 & Ocuc, Variety mixtures & 0,784 \\
\hline Soronko & 76 & 4.3 & Unknown local varieties & $\begin{array}{l}1,42,352,503,713,1471,1834, \\
2047,2479,4095\end{array}$ \\
\hline Mbale & 75 & 4.0 & Unknown local varieties & $\begin{array}{l}81,1175,1334,1471,1527,2039, \\
2045,2047,4095\end{array}$ \\
\hline Oyam & 31 & 1.5 & Variety mixtures, Bweyale-yellow & $386,1023,4095$ \\
\hline Maracha & 45 & 2.6 & $\begin{array}{l}\text { Ofuta ofuta, Agrupia, Wande- } \\
\text { wande, } \\
\text { Mvugupia, Koli kolia, K132 }\end{array}$ \\
\hline Zombo & 0 & 0.0 & $\begin{array}{l}\text { Cogudibi, Lau lau, Mixed varieties, } \\
\text { Nyar adranga, Ocidu, Nyar awora }\end{array}$ & None \\
\hline Kabarole* & - & - & Variety mixtures & $0,128,704,4095$ \\
\hline Kisoro* & - & - & Variety mixtures & $1094,1527,2023,2047,4095$ \\
\hline
\end{tabular}

*Incidence and severity data missing from these districts.

This study, however, revealed that races 4095 and 2047 were the most abundant and the races 4095, 2047, 2045, 2039 and 2023 were the most aggressive. This lack of consistency may be attributed to differences in areas sampled and/ or mutation of the pathogen to produce new pathotypes.

The Race 2047 is reported by de Lima Castro et al. (2017) as a Mesoamerican race. It is reported in Brazil to be one of the most aggressive of $C$. lindemuthianum races that can overcome anthracnose resistance conferred by seven resistance genes namely $\mathrm{Co}-1, \mathrm{Co}-2, \mathrm{Co}-3, \mathrm{Co}-4, \mathrm{Co}-5, \mathrm{Co}-6$ and $\mathrm{Co}-11$; and five alleles namely $\mathrm{Co}-1^{2}, \mathrm{Co}-1^{3}, \mathrm{Co}-1^{5}, \mathrm{Co}-3^{3}$ and $\mathrm{Co}^{-4}{ }^{3}$ (Darben et al., 2017). Mahuku and Riascos (2004) isolated race 2047 from materials from Costa Rica. The pathogenicity of the 27 races on the 12 differential cultivars is presented in Figure 2. The differential cultivar G2333 showed the highest number of resistant reactions followed by cultivars Cornell 49-242, TU and AB 136 respectively. This implies that these cultivars possess genes that confer broad-spectrum resistance to diverse C. lindemuthianum races in Uganda.

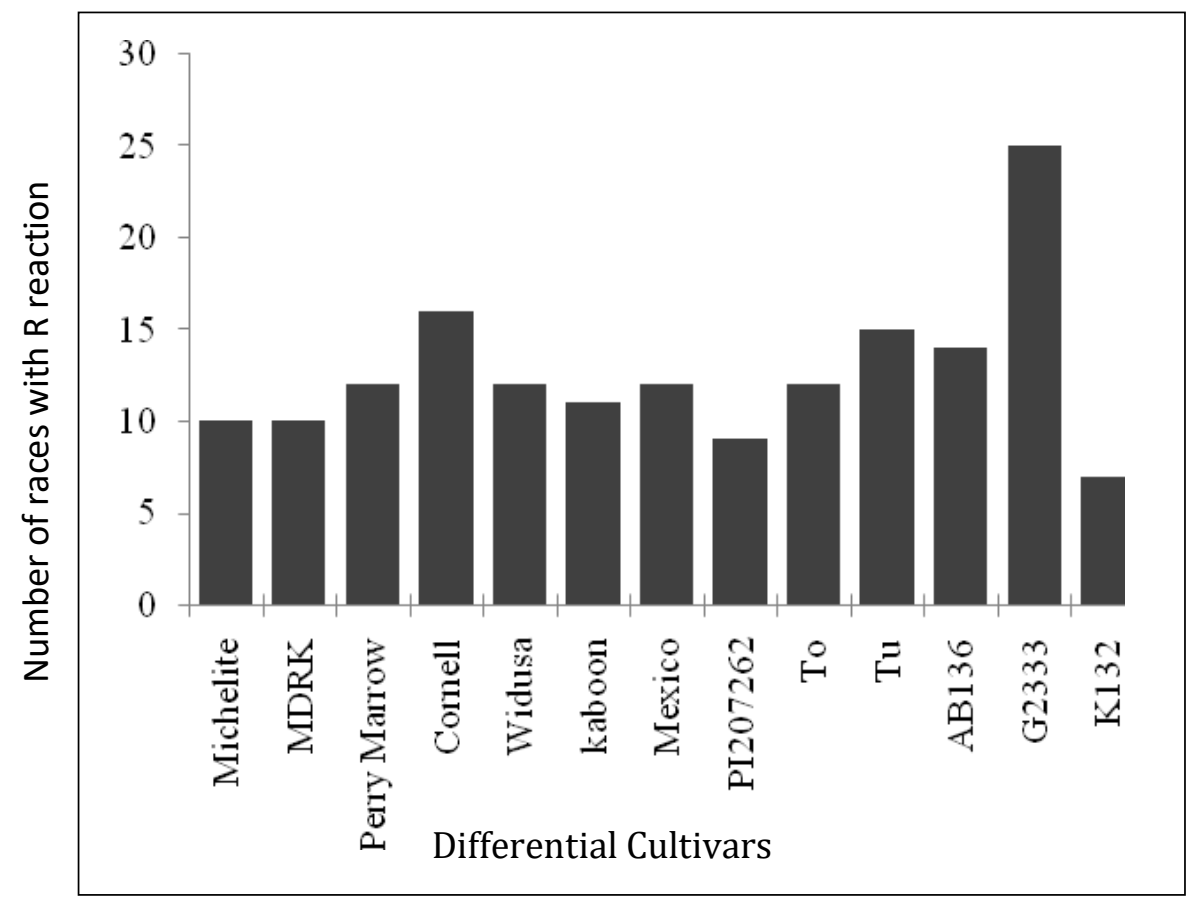

Figure 2. Pathogenicity of 27 races on 12 differential common bean cultivars and a susceptible check, K132 (CAL96). 
Bigirimana et al., (2000) also reported the cultivars TU, AB136 and G2333 to be highly resistant against 12 isolates from major bean growing areas in Burundi. Nkalubo (2006) reported cultivars G2333 and AB136 as the most resistant. However, Mwesigwa (2008) reported cultivar Widusa, which did not succumb to any of the 41 isolates, as the most resistant followed by G2333. This is contrary to what is widely observed in many studies and this particular study. Therefore, the cultivars G2333, Cornell 49-242, TU and AB 136 would be the best choices to use as donor parents in a breeding program aiming at increasing spectrum and durability of resistance against bean anthracnose. The highly effective resistance in cultivar G2333 is mostly attributed to its naturally occurring resistance gene pyramid comprising of $\mathrm{Co}^{-} 4^{2}, \mathrm{Co}-5$ and $\mathrm{Co}-7$ genes (Young et al., 1998). The allele $\mathrm{Co}-4^{2}$ is recognized as being among the most effective resistance genes described in common beans (Silverio et al., 2002). It was observed however, that, G2333 succumbed to two races namely 2479 and 4095 . Mwesigwa (2008) made a similar observation of G2333 succumbing to two races 3086 and 4033. Leaky and Simbwa-Bunnya (1972) observed that the immune nature of resistance in the cultivar Cornell 49-242, conferred by a single dominant gene $\mathrm{Co}-2$ (Mastenbroek, 1960), reduced the disease to a status of no importance in Holland but when tested in Uganda it showed clear anthracnose symptoms with five Ugandan isolates. In our study the cultivar Cornell 49-242 showed anthracnose symptoms with 11 races (Table 2).

The cultivars Michelite, MDRK and PI207262, respectively had the lowest number of resistant reactions. This implies that the resistance genes they carry are less broad-spectrum. These genes could still be useful in breeding programs targeting resistance gene pyramiding for broad spectrum resistance and/ or specific resistance to races $0,42,128,352,386,704,784$, 1094, 1334 and 1834 for cultivar Michelite; and races 0 , $1,42,81,352,784,1094,1334$ and 1834 for cultivar PI207262. Contrary to reports, the cultivar Michelite was not the most susceptible to the Ugandan $C$. lindemuthianum races, instead it was the cultivar PI207262 that succumbed the most.

\section{CONCLUSION}

Colletotrichum lindemuthianum showed a high pathogenic variation in Uganda with 27 races identified from the sampled bean growing areas. Pathogenic variation was highest in the Eastern and South Western highland regions of Uganda.Two of these races namely 2479 and 4095 were aggressive enough to cause a susceptible reaction on the highly resistant cultivar G2333.

Gene pyramiding could offer a more effective and broad spectrum resistance to $C$. lindemuthianum population in Uganda. Therefore, further studies could investigate effectiveness of pyramided genes in conferring broad spectrum resistance against $C$. lindemuthianum races in Uganda and further develop common bean cultivars with pyramided anthracnose resistance genes.

The differential cultivars G2333, Cornell 49-242, TU and AB136 are recommended for use as sources of resistance in breeding programs aiming at broadspectrum resistance to $C$. lindemuthianum in Uganda.

\section{ACKNOWLEDGEMENT}

Uganda National Council of Science and Technology (UNCST) funded the study through the Millennium Science Initiative (MSI) project. Additional funding was provided by CIAT-Uganda and the ATAAS project under the National Agricultural Research Organization (NARO).

\section{REFERENCES}

Balardin, R.S. and Kelly, J.D. 1998. Interaction among races of Colletotrichum lindemuthianum and diversity in Phaseolus vulgaris. Journal of American Society of Horticultural Sciences. 123:1038-1047.

Balardin, R.S., Jarosz, M. and Kelly, J.D. 1997. Virulence and molecular diversity in Colletotrichum lindemuthianum from South, Central, and North America. Phytopathology 87: 1184-1191.

Bigirimana, J., Fontaine, R. and Hofte, M. 2000. Bean anthracnose: virulence of Colletotrichum lindemuthianum isolated from Burundi, Central Africa. Plant Disease. 84: 491.

Champion, M.R., Brunet, D., Maudit, M.L., Ilami, R. 1973. Methode de controle de la resistance desvarietes de haricots a l'antracnose (Colletotrichum lindemuthianum (Sacc \& Magn.) Briosi et Cav. C. R. Hebd. Seances Acad Agric Fr 59:951-958. English Abstract.

Darben, L.M., Gonela, A., Elias, H.T., Pastre, H.H. and Goncalves-Vidigal, M.C. 2017. Common bean germplasm resistant to races 73 and 2047 of Colletotrichum lindemuthianum. African Journal of Biotechnology. Vol.16(19), pp. 1142-1149. DOI: 10.5897/AJB2016.15751.

de Lima Castro, S.A., Gonçalves-Vidigal, M.C., Gilio, T.A.S., Lacanallo, G.F., Valentini, G., Martins, V.S.R., Song, 
Q., Galván, M.Z., Hurtado-Gonzales, O.P. and Pastor-Corrales, M.A. 2017. Genetics and mapping of a new anthracnose resistance locus in Andean common bean Paloma. BMC Genomics (2017) 18:306. DOI 10.1186/s12864-017-3685-7.

Gonçalves-Vidigal, M.C., Silva, C.R., Vidigal Filho, P.S., Gonela, A., Kvitschal M.V. 2007. Allelic relationships of anthracnose (Colletotrichum lindemuthianum) resistance in the common bean (Phaseolus vulgaris L.) cultivar Michelite and the proposal of a new anthracnose resistance gene, Co-11. Genetics and Molecular Biology. 30:589-593.

Inglis, D.A., D.J. Hagedorn and Rand, R.E. 1988. Use of dry inoculum to evaluate beans for resistance to anthracnose and angular leaf spot. Plant Disease 72:771-774.

Kelly, J.D. and Vallejo, V.A. 2004. A comprehensive review of the major genes conditioning resistance to anthracnose in common bean. HortScience 39:1196-1207.

Leaky, C.L.A. and Simbwa-Bunnya, M. 1972. Races of Colletotrichum lindemuthianum and implications for bean breeding in Uganda. Annals of Applied Biology 70: 25-34.

Mahuku, S.G. and Riascos, J. J. 2004. Virulence and molecular diversity within Colletotrichum lindemuthianum isolates from Andean and Mesoamerican bean varieties and regions. European Journal of Plant Pathology 110: 253-263.

Mastenbroek, C. 1960. A breeding program for resistance to anthracnose in dry shell haricot beans, based on a new gene. Euphytica 9: 177 - 184.
Mwesigwa, J.B. 2008. Diversity of Colletotrichum lindemuthianum and reaction of common bean germplasm to anthracnose disease. MSc. Thesis. Makerere University. Uganda.

Nkalubo, S.T. 2006. Physiological races of dry bean anthracnose (Colletotricum lindemuthianum) in Uganda. PhD thesis. University of KwaZulu Natal. South Africa.

Pastor-Corrales, M.A. 1991. Estandarización de variedades diferenciales y de designación de razas de Colletotrichum lindemuthianum. Phytopathology 81:694.

Pastor-Corrales, M.A., Otoya, M.M. and Molina, A. 1995. Resistance to Colletotrichum lindemuthianum isolates from Middle America and Andean South America in different common bean races. Plant Disease. 79:63-67.

Schwartz, H. and Pastor-Corrales, M.A. 1989. Bean Production Problems in the Tropics. Verlag Josef Margraf. ISBN-10: 382361147X.

Silverio, L., Vidigal, M.C., Vidigal Filho, P.S., Barelli, M.A.A., Thomazell, C. and Nunes, W.M.C. 2002. Genetic resistance to $C$. lindemuthianum race 2047 in G2333. Annual Report. Bean Improvement Coop. 45:74-75.

Young, R.A., Melotto, M., Nodari, R.O. and Kelly, J.D. 1998. Marker-assisted dissection of the oligogenic. Theoretical and Applied Genetics. Springer. 96: 87-94. 